\title{
Distribution and habitat condition of the endangered benthic animals associated with salt marsh in Tokyo Bay, Japan
}

\author{
柚原 剛 11,4$)$, * 高木 俊 ${ }^{2), 5)}$ ・風呂田利夫 ${ }^{3)}$ \\ ${ }^{1)}$ 東邦大学大学院理学研究科 $\bar{T} 274-8510$ 千葉県船橋市三山 2-2-1 \\ 2) 東邦大学理学部 $\overline{7} 274-8510$ 千葉県船橋市三山 2-2-1 \\ 3) 東邦大学理学部東京湾生態系研究センター $7274-8510$ 千葉県船橋市三山 2-2-1

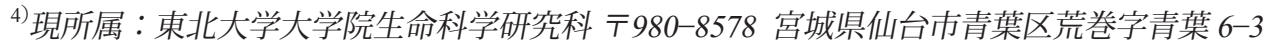 \\ ${ }^{5)}$ 現所属：兵庫県立人と自然の博物館 テ 669-1546 兵庫県三田市弥生が丘 6
}

\author{
Takeshi YUHARA ${ }^{1), 4), *}$, Shun TAKAGI ${ }^{2), 5)}$ and Toshio FUROTA ${ }^{3)}$ \\ 1) Graduate School of Science, Toho University, Miyama 2-2-1 Funabashi, Chiba 274-8510, Japan \\ 2) Faculty of Science, Toho University, Miyama 2-2-1 Funabashi, Chiba 274-8510, Japan \\ 3) Tokyo Bay Ecosystem Research Center, Toho University, Miyama 2-2-1 Funabashi, Chiba 274-8510, Japan \\ 4) Graduate School of Life Science, Tohoku University, Aoba 6-3, Aramaki, Aoba-ku, Sendai, Miyagi 980-8578, Japan \\ 5) Museum of Nature and Human Activities, Hyogo, Yayoigaoka 6, Sanda, Hyogo 669-1546, Japan
}

\begin{abstract}
We investigated the spatial distribution of macrobenthos in salt marshes along the coast of Tokyo Bay, with environmental factors that influence their distribution. The field survey was conducted at 31 sites along the entire coast of the bay, in which presence or absence of the salt marsh animals and environmental factors (salinity, ORP, median grain size, elevation, vegetation area) of the habitats were examined. Most of common species of mollusks and crustaceans were distributed on entire coast of the bay, but some of endangered species showed restricted distribution in the coast. The restricted distribution of endangered salt marsh crabs were explained by several environmental factors; higher salinity and lower elevation of the habitat were suitable for Helicana japonica and Parasesarma affines, which were distributed in eastern coast in the bay, and Sesarmops intermedium, that was distributed in western coast and inner part, tended to inhabit higher elevation sites. Since local populations of these salt marsh species in the bay may be consisted of bay scale metapopulation that are formed by connectivity between small local populations through larval dispersal, distributional restriction of the salt marsh crabs in the bay may indicate that these endangered species are regarded as being difficult to persist in the bay. New local populations of the salt marsh benthos animals could be restored by creation of salt marsh habitats along the bay, to increase of the connectivity between local populations in the bay.
\end{abstract}

Key Words: benthic invertebrates, endangered species, conservation, saltmarsh, Tokyo Bay

\section{はじめに}

塩性湿地の成立基盤である河口干潟生態系は, 人間活動 による過剩な開発，污濁，埋立などにより消失や深刻な摚 乱を受けており（Lotze 2006）, 日本では，20世紀後半で $40 \%$ 以上の干潟域が消失した（日本ベントス学会 2012）. 中でも首都圈にある東京湾は工業化・都市化による沿岸開 発が著しく, 塩性湿地の成立基盤である干潟面積は, 戦前 （1945 年以前）の 13,600 ha から一時約 1,000 ha まで減少 した．近年ではその再生として人工的な干潟造成も行わ

\footnotetext{
Received 2 February 2015 Accepted 2 October 2015

* Corresponding author

E-mail: yugo88@nifty.com
}

れ，1997 年の時点で 1,640 ha とされる（古川 2011）。干潟 の中の塩性湿地植生帯面積は, 明治時代中期では湾奥部や 河口部中心に約 810 ha（農業環境技術研究所 - 歴史的農業 環境閲覧システム提供の迅速測図より判読）が認められた ものの, 現在は人工的に改変あるいは造成された干潟内の 塩性湿地を含めても約 83 ha（Google map 提供の衛星画像 より判読）と約 $90 \%$ が消失した. 塩性湿地に生息する主 要なベントスは塩性湿地環境依存性が高く（風呂田 2011)，このような埋立による河口域の干潟や塩性湿地の 消失により，ここに生息するベントス種の多くが地域的な 絶滅の危機に瀕している（風呂田 2007; 千葉県レッドデー タブック改訂委員会 2011; 柚原ら 2013)。このような塩性 湿地に依存的なベントスの個体群の衰退は, 日本全国規模 で起こっており, 生物多様性の保全と再生の課題となって いる (Sato 2010). 
干潟や塩性湿地を含む沿岸環境の劣化による生物多様性 の減少を食い止めるには，そこに生息する生物の分布とそ の生息環境の現状を正確に把握したうえで適切な保全策を 実施することが必要とされる（プリマック・小堀 2008; 日 本ベントス学会 2012). 塩性湿地に生息するベントス種の 多くは, 生活史の初期をプランクトン幼生として海域に分 散し, ベントス生活場に着底して個体群を形成する, プラ ンクトン幼生分散を前提とした局所個体群間の交流による メ夕個体群を形成しているとされる（風呂田 2000; Grimm et al. 2003; Kritzer \& Sale 2006; Sale et al. 2006; Kumar et al. 2012). そのため, ベントスの分布特性を明らかにする上 では, メ夕個体群の視点に基づいた局所個体群間の連結性 および局所個体群内の生息環境の質を考慮した調査研究が 求められる (Hanski 1999; Thomas et al. 2001; Fleishman et al. 2002). 内湾スケールで複数の塩性湿地を統合的に調查 した例は, 日本においては, 三河湾および伊勢湾での腹足 類相を報告した木村・木村（1999）, 東京湾内湾の塩性湿 地を含む干潟ベントス相を報告した柚原ら（2013）があ る。柚原ら（2013）では, 東京湾の塩性湿地を含む 26 力 所の干潟で調査を実施し, 塩性湿地に絶滅危惧ベントスが 多く生息していたことを明らかにした。また絶滅危惧ベン トスの一部は, 湾内で偏在分布を示す傾向にあり, その原 因については今後の調査の進展に委ねていた. しかし, 柚 原ら（2013）でも, ベントスの分布特性と生息環境につい ては評価を行っておらず, 東京湾岸全域のスケールで塩性 湿地性ベントスの分布特性, それに影響する生息環境選好 性との対応を示した研究例はない.

そこで本研究では, 東京湾内に残存する塩性湿地の存在 状況を把握したうえで, そのほぼすべての塩性湿地を調査 地として設定し，そこに生息するベントスの代表的生物群 である腹足類と甲殼類の生息に要求される環境要因, なら びに分布の偏在化の原因を明らかにすることを目的とし た.そのうえで, 得られた知見をもとに, 過去の東京湾心゙ ントス相の記録を比較するとともに, 東京湾岸における塩 性湿地性絶滅危惧ベントスの保全策を検討した。

\section{材料と方法}

\section{調査地}

東京湾内湾部（富津岬一観音崎以北）におけるヨシ Phragmites australis やアイアシ Phacelurus latifolius からな る塩性湿地の存在場所を, Google map の衛星画像の判読, 研究者からの情報, ならびに現地踏査から抽出した. 31 カ所の塩性湿地を伴う干潟を調査地として選定し, 東京湾 における塩性湿地を含む干潟をほぼ網羅した。各調査地の 位置を Fig. 1 に示し，その概況を Table 1 に記す。このう ち 16 カ所の調查地のベントス出現種については, 2008 年 から 2011 年にかけて行った柚原ら（2013）の結果を用い, 残りの 15 力所の調査地においては, 2011 年と 2012 年に
かけて調査を行った. 各塩性湿地の地形的特徵は, 日本べ ントス学会（2012）に従い「河口干潟」,「河川干潟」,「潟 湖干潟」の 3 区分に加え, 調查地に特徵的に見られる人工 水路内の干潟として「人工水路干潟」のいずれかに分類し た（Table 1)。「河口干潟（River-mouth tidalflat）」は河口部 周辺に形成された干潟, 河川から運ばれた砂泥の沈降, 堆 積により形成されるもので, 入江奥部に形成された河川開 口部の干潟も含まれる。「河川干潟（River tidalflat）」は河 口干潟の中で河川内の感潮域に形成された干潟である. 「潟湖干潟（Lagoon tidalflat）」は砂州などにより形成され た閉鎖的な潟湖内の干潟であるが，東京湾の場合は自然状 態の潟湖はなく，ここでは埋立により形成された人工的な 地形である。これらに加え, 東京湾沿岸域, 特に湾東岸を 占める千葉県側では, 戦後の埋立地造成に際して, 既成市 街地と工業地域を分離し後背地の排水機能を維持するため に, 旧海岸線と埋立地の境界部に幅 $20 \sim 40 \mathrm{~m}$ の小規模な 人工感潮水路が造成されており（伊藤・伊藤 1983 ; 永江 2006）, この水路内に二次的に形成された干潟を「人工水 路干潟（Artificial channel tidalfalt）」とした.

\section{ベントス生息調査}

調査は2008２011 年にかけて行われた柚原ら（2013） の結果を使用し，そこで調査していなかった箇所について は，2012 年に 5 10月にかけて行った。また多摩川河口 干潟に関しては，2012 年 7 月〜 10月にかけて行った柚原 ら（2015）の結果も加えた．全ての調査は，干潟ベントス の種多様性ならびに希少種・絶滅危惧種の生息を把握する ため, 生息密度の低い種の発見効率が高い目視による定性 調査法を採用した（環境省自然環境局 2007）。調査範囲は $50 \mathrm{~m}$ 方形内を原則とし，岸に沿った潮間帯幅が $50 \mathrm{~m}$ 未満 の場合にでも一辺の長さを変えて $2500 \mathrm{~m}^{2}$ 相当の調査範囲 を確保した。各調査地を最低 3 回以上訪れ, 打ち上げ物や 植物堆積物中や下も含め生息するすべての表在性ベントス を採集し，各調査地でのベントス種の在・不在を記録し た。得られたベントスの中から，風呂田（2007）, 環境省 自然環境局（2007）などの既存の知見を参照し，塩性湿地 ならびにその周辺に生息する表在性ベントスを解析対象と した.

本研究における東京湾内での希少種および絶滅危惧干潟 ベントスは，以下のように定義した．1）千葉県レッド データブック動物編 2011 年改訂版（千葉県レッドデータ ブック改訂委員会 2011）で「消息不明・絶滅生物」,「最 重要保護生物」「重要保護生物」と評価された種，2）干 潟の絶滅危惧動物図鑑（日本ベントス学会 2012）で掲載 されている種で, 東京湾において局所個体群の存在する生 息地点数もしくは各局所個体群内での個体数の減少がみら れる種とした。 

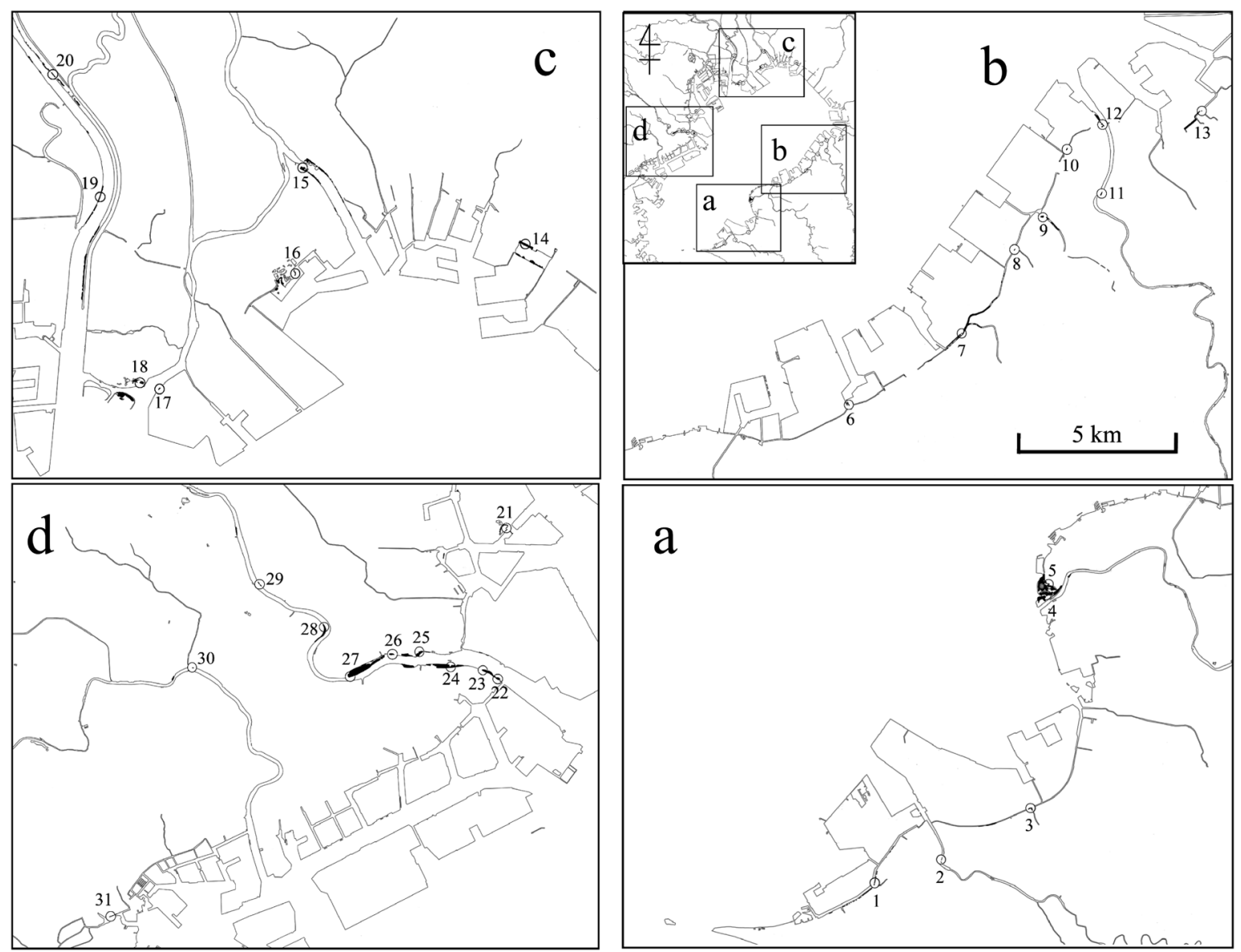

Fig. 1. Maps of the survey sites. The black area indicates the reed marsh vegetation. See also Table 1 for further details.

\section{環境要因}

2012 年 10 月にすべての調査地で, 底質環境として間隙 水塩分, 酸化還元電位 (ORP), 底質粒径中央值を測定し た. 以上の底質環境要因は河口域のベントス各種の分布域 を決める主要因とされている（小林 2000 , 楠田・森 2008). 間隙水の塩分は各調査地の底質を小型スコップで 掘り, 沴出した間隙水をプラスチック容器で採取し, 室内 にて $1 / 2$ 標準海水で補正した塩分計（YK-31SA: FUSO 社） で 0.1 PSU 精度で測定した。 ORP は，ORP 電極（RM-20P: 東亜ディーケー社）を用いて，表面から深さ $1 \mathrm{~cm}$ で測定 した。底質粒径中央值は各調査地の表面 $1 \mathrm{~cm}$ の底土を大 さじ 1 杯分採集し, 室内にてレーザー回折式粒度分析装置 （島津製作所：SALD-3100）を用いて粒径の中央值を求め た。これらの環境要因は各調査地内で無作為に 3 カ所から 測定し, その平均值を解析に使用した.

生息場の地盤高とヨシならびにアイアシからなる植生域 の面積は塩性湿地の空間構造において基盤的要因である. 地盤高は国土地理院基盤地図情報（数值標高モデル $5 \mathrm{~m}$ メッシュ）より, $10 \mathrm{~cm}$ 単位で各調査地点における調査範 囲の標高值の平均值を算出した。ヨシならびにアイアシか らなる植生面積は, Google Maps 面積計算ツールを使用し (http://foonyan.sakura.ne.jp/), 衛星写真をもとに調査地点 を含むひとまとまりの植生面積を求めた。なお本研究は, 2011 年 3 月の東北地方太平洋沖地震を前後して実施され, 東京湾沿岸域の干潟域にも, 局所的に地盤沈下等の物理的 改変が報告されている（風呂田ら 2012）。しかし, 本研究 の調査箇所の塩性湿地では, 風呂田ら（2012）で報告され た新浜湖を除いて, 地盤沈下等の物理的改変は報告されて おらず，東北地方太平洋沖地震をまたいでの環境への影響 は少ないとした。

\section{統計解析}

測定した環境要因が絶滅危惧種を含む塩性湿地に生息す るベントスの分布に及ぼす影響を検討するため，小幡ら （2012）に従い, 全調查地中での出現頻度が $20 \%$ 以上の種 を，統計解析を行うために十分なデータが存在する種とし て解析対象とした。ただし, クロベンケイガニChiromantes dehaani は全調查地で出現したため, 解析対象外とし た。各調査地でのベントスの在・不在を目的変数, 環境要 因として塩分, ORP, 底質粒径中央值, 地盤高, ヨシ・ア イアシ植生面積, また空間自己相関項として緯度経度座標 （1３ 次項）（Lichstein et al. 2002）を説明変数とし, 一般 


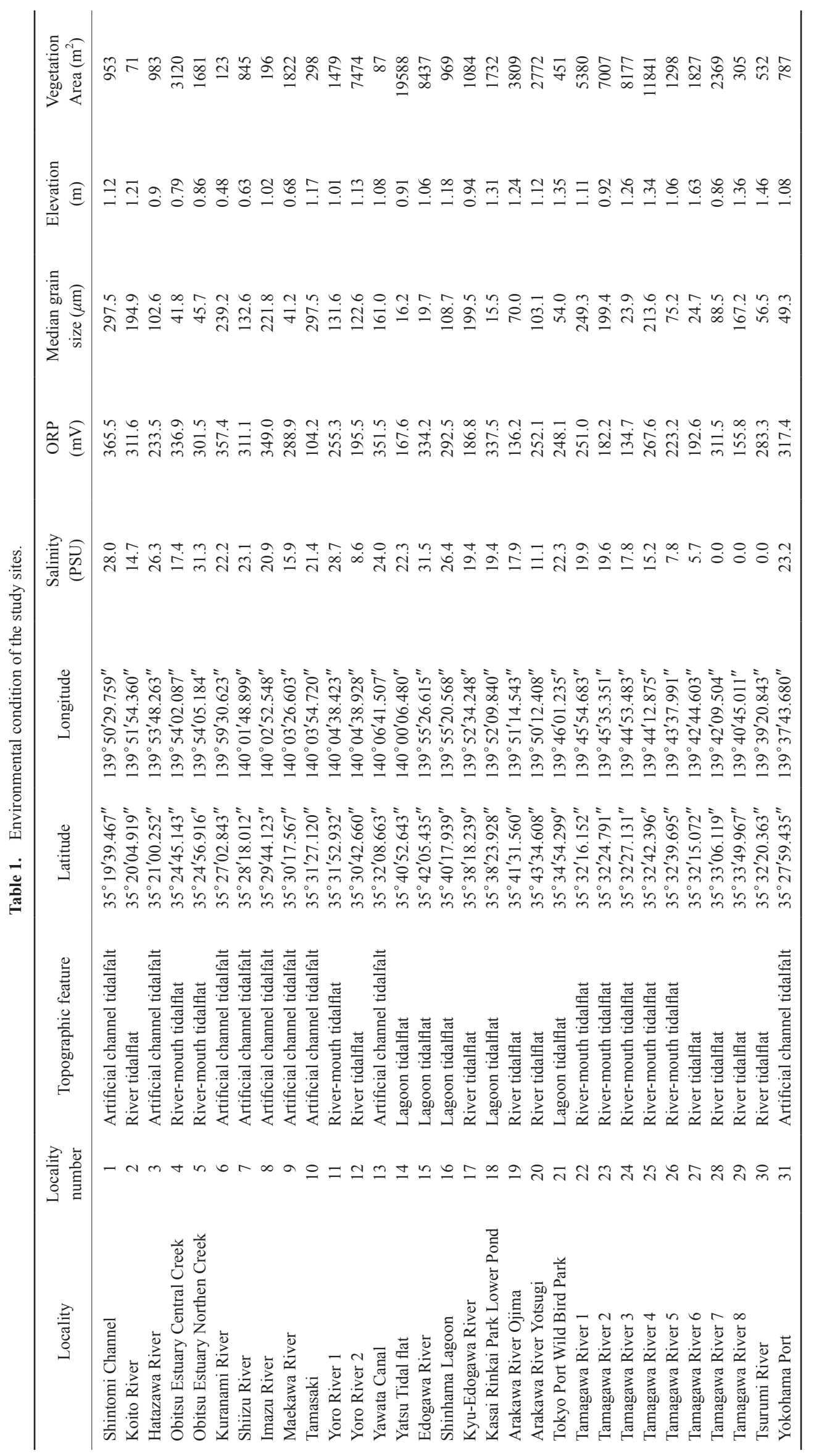




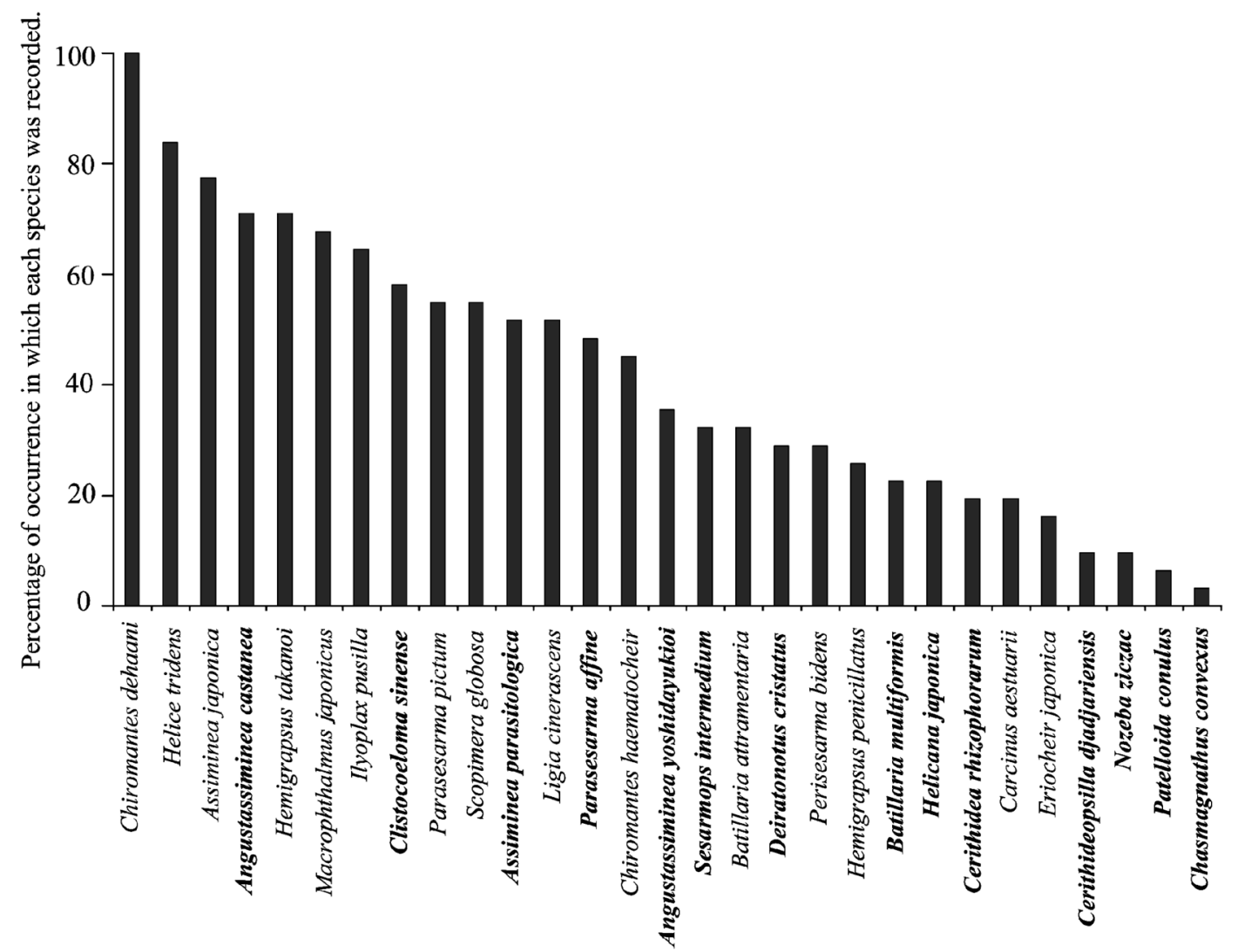

Fig. 2. Proportion of occurring sites of the macrobenthic species in Tokyo Bay. Bold species indicate endangered species.

化線形モデル（誤差構造：二項分布，リンク関数：ロジッ ト）によって要因の効果を把握した. 環境要因の寄与を比 較するため, 説明変数は標準化したのちに解析に用いた. すべての変数の組み合わせからなる候補モデルを作成し， 赤池情報量規準（AIC）に基づくモデル選択を行った. 経 験的に AIC の差が 0 2 のモデルは考慮する価值のあるモ デルとされる（Burnham \& Anderson 2002）。またベストモ デルとの AIC の差が 2 以内のモデルに関して, 各モデル の相対的な重要性を示す Akaike weight を算出した. 各変 数の影響力はモデルアベレージングを行い, 係数の推定值 をその標準䛊差で割った值（Z 值）を Akaike weight で重 み付け平均した值で評価した， $\mathrm{Z}$ 值の絶対值が 2 を超える ものは「影響力が強い変数」とされる（Burnham \& Anderson 2002). 説明変数間の相関（多重共線性）の存在は, 変数の影響力を判断するのを困難にするため, 階層分割を 行い, 他の説明変数の効果と混同されない独立効果 (independent effect）と, 他の説明変数の効果と分離できない連 結効果（joint effect）を計算した（MacNally 2000). 各説 明変数の独立効果は, その変数をモデルに追加することに よって改善するモデルの適合度を, 可能なすべての組み合 わせのモデルで計算し, その值を平均することによって計 算される. 連結効果は, その変数のみを説明変数としたモ デルの適合度（Total effect）から, 独立効果を差し引いた
值で定義される. 本研究では, 最大対数尤度をモデルの適 合度の指標として使用した，独立効果の有意性は 1000 回 の組み替えによる無作為化検定によって評価した。これら すべての解析には R.2.15.2（R Core Team 2012）を使用し た.

\section{結果}

全調査地で塩性湿地依存性の表在性腹足類と甲殼類は計 29 種が確認された（Table 2). 表在性ベントス各種の出現 頻度, 出現地を Fig. 2, Fig. 3 に示す. 全調査地の $20 \%$ 以 上で確認された種は, 出現調査地点数の多い順に, クロベ ンケイガニ, アシハラガニHelice tridens (Fig. 3A), カワ ザンショウガイ Assiminea japonica (Fig. 3B)， クリイロカ ワザンショウ Angustassiminea castanea (Fig. 3C), タカノ ケフサイソガニ Hemigrapsus takanoi (Fig. 3D), ヤマトオ サガニMacrophthalmus japonicus（Fig. 3E），チゴガニIlyoplax pusilla (Fig. 3F), ウモレベンケイガニClistocoeloma sinense (Fig. 3G), カクベンケイガニParasesarma pictum (Fig. 3H)，コメツキガニScopimera globosa (Fig. 3I)，ヒ ナタムシャドリカワザンショウ Assiminea parasitologica (Fig. 3J), キタフナムシ Ligia cinerascens (Fig. 3K), クシ テガニ Parasesarma affine (Fig. 3L), アカテガニChiro- 


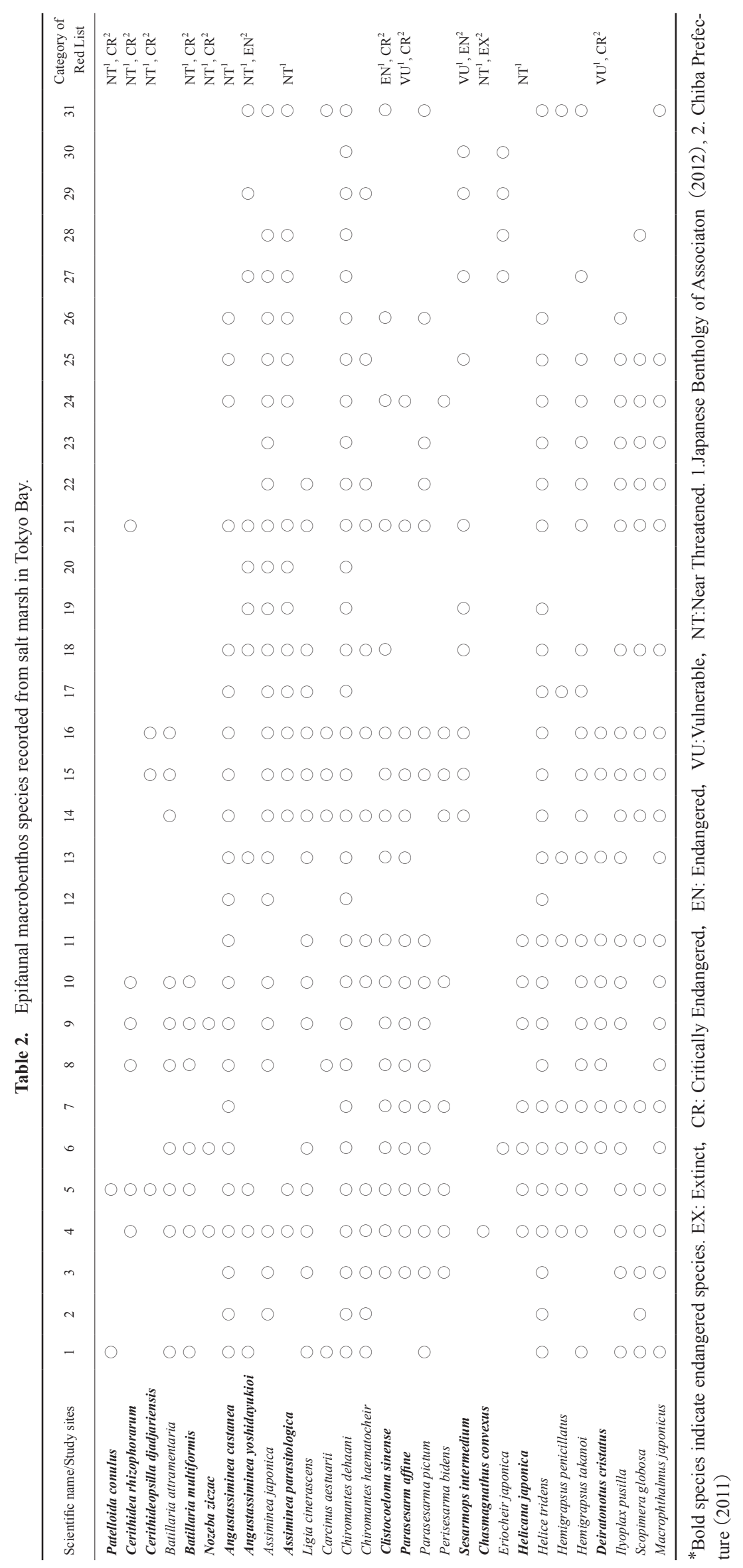




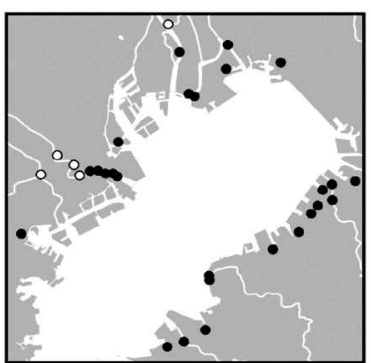

A: Helice tridens

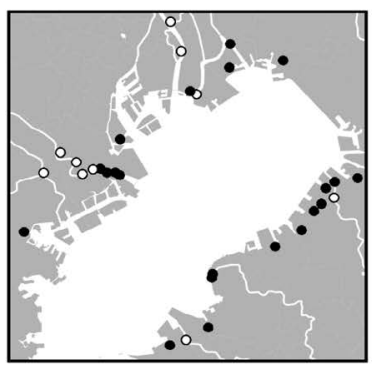

E: Macrophthalmus japonicus

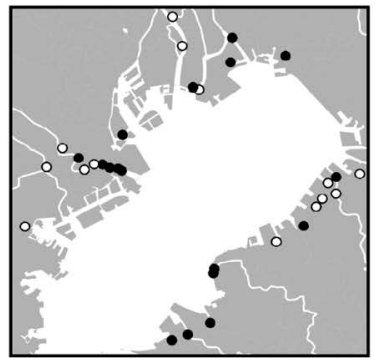

I: Scopimera globosa

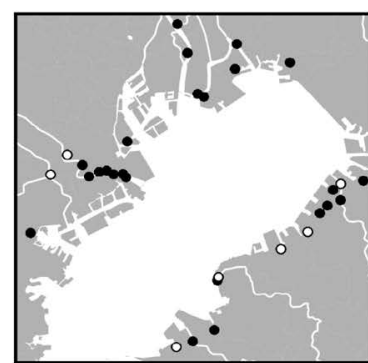

B: Assiminea japonica

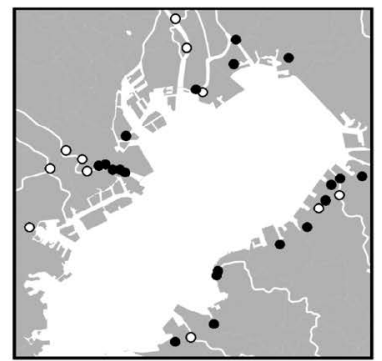

F: Ilyoplax pusilla

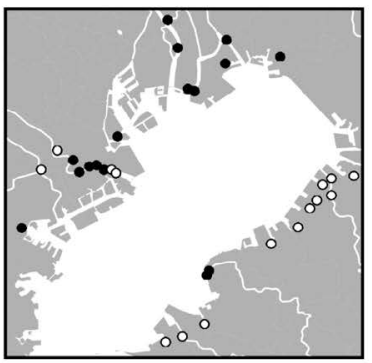

J: Assiminea parasitologica

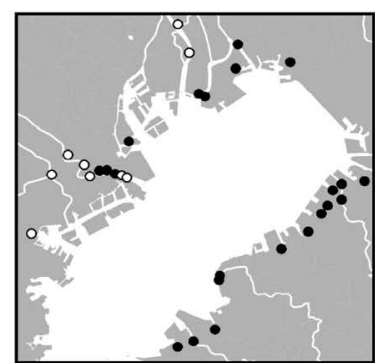

C: Angustassiminea castanea

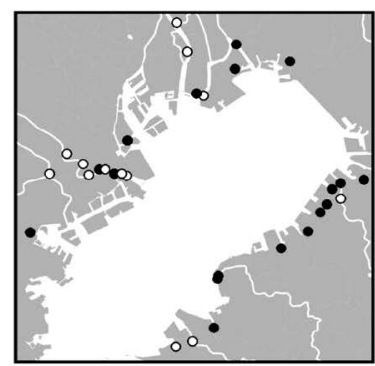

G: Clistocoeloma sinense

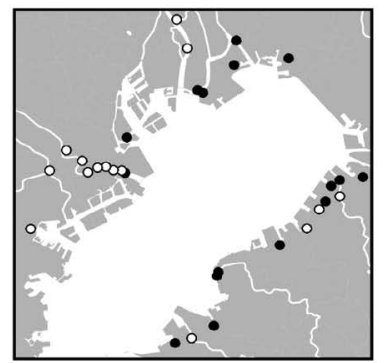

K: Ligia cinerascens

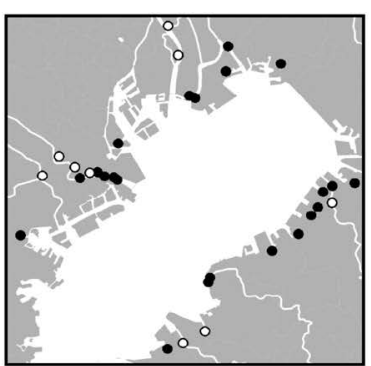

D: Hemigrapsus takanoi

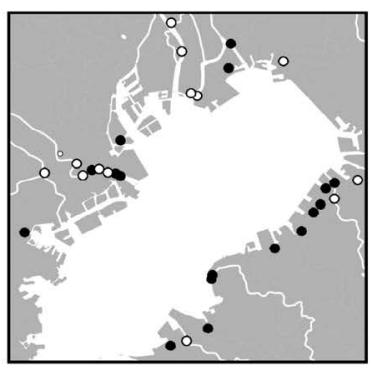

H: Parasesarma pictum

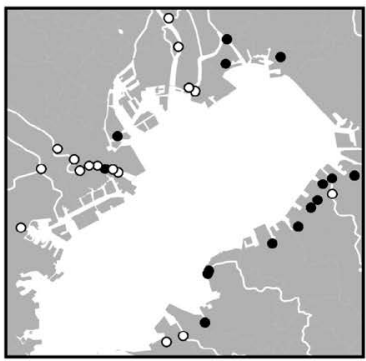

L: Parasesarma affine

Fig. 3. Distribution pattern of the macrobenthic species in Tokyo Bay. Closed circles are presence at the study sites. Open circles are absence at the study sites.

mantes haematocheir (Fig. 3M)，ヨシダカワザンショウ Angustassiminea yoshidayukioi (Fig. 3N), ベンケイガニ Sesarmops intermedium (Fig. 30), ホソウミニ ナBatillaria attramentaria (Fig. 3P), アリアケモドキDeiratonotus cristatus (Fig. 3Q)，フタバカクガニ Perisesarma bidens（Fig. 3R), ケフサイソガニ Hemigrapsus penicillatus（Fig. 3S）, ウミニナ Batillaria multiformis (Fig. 3T), ヒメアシハラガ 二Helicana japonica（Fig. 3U）の 22 種であった. 残り 7 種のフトヘナタリCerithidea rhizophorarum (Fig. 3V), チ チュウカイミドリガニCarcinus aestuarii, モクズガニ Eriocheir japonica, カワアイ Cerithideopsilla djadjariensis, サ ザナミツボ Nozeba ziczac, ツボミPatelloida conulus, ハマ ガニ Chasmagnathus convexus は 20\%未満の調査地で確認 された低頻度出現種であった。

高頻度出現種のなかで, クシテガニ, フトヘナタリ，ア リアケモドキ, ヒメアシハラガニ, ウミニナは主に湾東岸 を中心に出現し, クシテガニ, ホソウミニナ, アリアケモ ドキ, フタバカクガニ, ケフサイソガニはさらに湾奥で出
現した。一方，ヒナタムシヤドリカワザンショウ，ヨシダ カワザンショウ, ベンケイガニは湾西岸を中心に湾奥でも 出現した。

高頻度出現ベントス種を対象に，一般化線形モデルによ るモデルアベレージングを行った結果を Fig. 4 に示す。な おフトヘナタリは出現頻度が $20 \%$ 未満であるが塩性湿地 依存種とされているため解析に加えた。その結果, アシハ ラガニ, ウモレベンケイガニ, カクベンケイガニで, その 出現と塩分との間に対し強い正の応答を示す関係が見られ た。

階層分割による, 希少種・絶滅危惧種の出現に対する各 説明変数の独立効果の計算結果を Fig. 5 に示す. 塩分はア シハラガニ, タカノケフサイソガニ, ヤマトオサガニ, チ ゴガニ, ウモレベンケイガニ, カクベンケイガニ, コメッ キガニ, キタフナムシ， クシテガニの出現に対し有意な独 立効果を示した. 底質粒径中央值はウモレベンケイガニ, ヒナタムシヤドリカワザンショウの出現に対し有意な独立 効果を示した. 地盤高はベンケイガニ，ケフサイソガニ, 


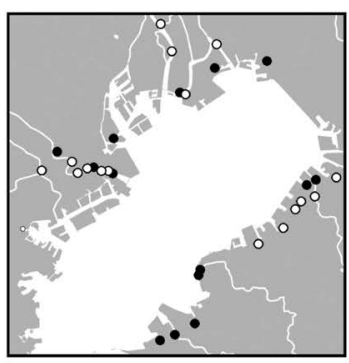

M: Chiromantes haematocheir

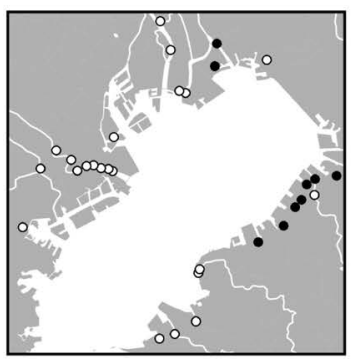

Q: Deiratonotus cristatus

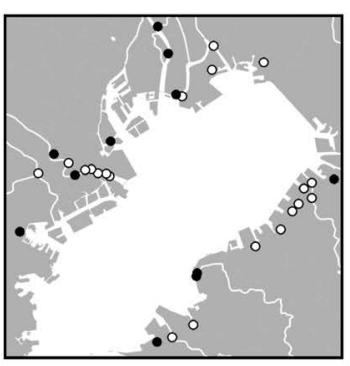

$\mathbf{N}$ : Angustassiminea yoshidayukioi

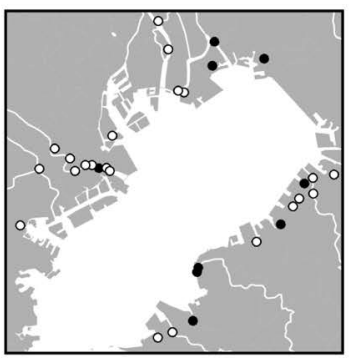

R: Perisesarma bidens

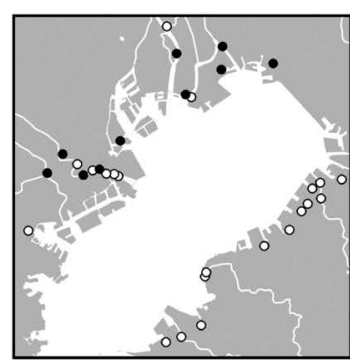

O: Sesarmops intermedium

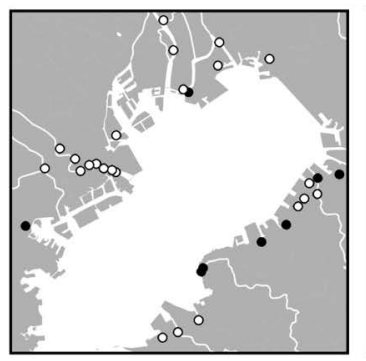

S: Hemigrapsus penicillatus

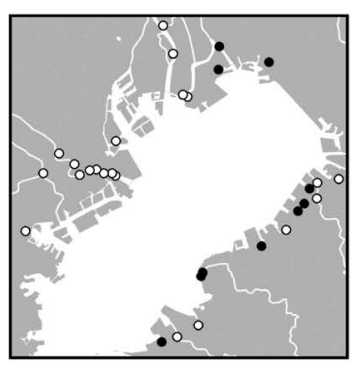

P: Batillaria attramentaria

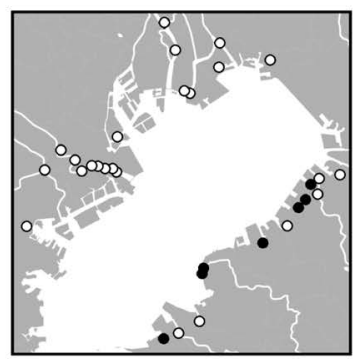

T: Batillaria multiformis

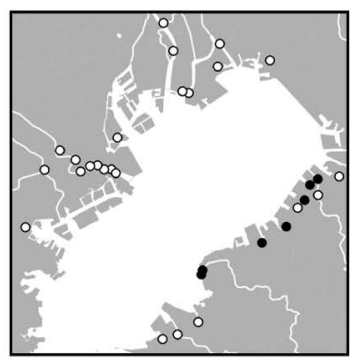

U: Helicana japonica

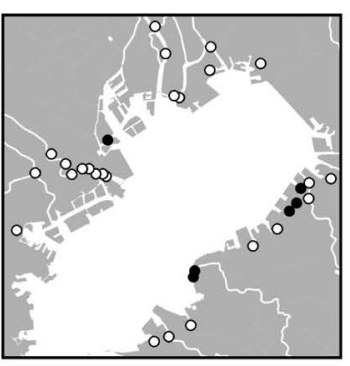

V: Cerithidea rhizophorarum

Fig. 3. continued

ヒメアシハラガニの出現に対し有意な独立効果を示した. ORP およびヨシ・アイアシ植生面積は，いずれのベント スの出現に対しても独立効果は有意ではなかった，空間自 己相関項は, カワザンショウガイ, ヤマトオサガニ, チゴ ガニ, コメツキガニ, ウモレベンケイガニ, ケフサイソガ 二では, 1 から 3 次項のすべてにおいて有意な独立効果が 無かったが, 他のベントスの出現に対してはいずれかの項 において有意な独立効果が示された。

Table 3 に一般化線形モデルの結果から得られた各種の 出現に対する環境要因の正負の方向性および階層分割によ り有意な独立効果を示した変数の結果をまとめた。ほとん どのベントスでは有意な独立効果を示したのが塩分のみで あり，すべて正の効果であった，それ以外の変数に有意な 独立効果を示したベントスは, ウモレベンケイガニ, ヒナ タムシヤドリカワザンショウ, ベンケイガニ, ケフサイソ ガニ, ヒメアシ八ラガニの 5 種であり, ケフサイソガニを 除いて絶滅危惧種であった。分類群別にみると, 腹足類に 関しては，ヒナタムシャドリカワザンショウの出現に対し
て底質粒径中央值が負の独立効果を示したのみで，他の腹 足類の出現は環境要因では説明できなかった。甲殼類では アリアケモドキ，アカテガニ，フタバカクガニを除いた種 の出現は環境要因, 特に塩分で説明された。湾東岸に偏在 的に出現した希少種・絶滅危惧種では，クシテガニが塩分 に対し正の応答を示し, ヒメアシハラガニは地盤高に対し 負の応答を示した。一方，湾西岸に偏在的に出現した希少 種・絶滅危惧種では，ヒナタムシャドリカワザンショウが 底質粒径中央值に対し負の応答を示し, ベンケイガニが地 盤高に対し正の応答を示した。湾全域で出現したクリイロ カワザンショウに関しては環境要因では説明できず，ウモ レベンケイガニは塩分に対し正の応答および底質粒径に対 し負の応答を示した.

\section{考察}

本研究では, 東京湾における 31 力所の塩性湿地を伴う 干潟において, 腹足類と甲殼類を中心とした表在ベントス 
Table 3. Effects of each environmental variable on occurrence of the macrobenthic species. + ; represents positive effect. - ; represents negative effect. Half-tone dot meshing represents crustacean species..

\begin{tabular}{|c|c|c|c|c|c|c|}
\hline Species name & Salinity & ORP & $\begin{array}{l}\text { Median } \\
\text { grain size }\end{array}$ & Elevation & $\begin{array}{l}\text { Vegetation } \\
\text { area }\end{array}$ & $\begin{array}{c}\text { Auto } \\
\text { correlation }\end{array}$ \\
\hline Helice tridens & + & & & & & $*$ \\
\hline $\begin{array}{l}\text { Assiminea japonica } \\
\text { Angustassiminea castanea }\end{array}$ & & & & & & * \\
\hline $\begin{array}{l}\text { Hemigrapsus takanoi } \\
\text { Macrophthalmus japonicus } \\
\text { Ilyoplax pusilla } \\
\text { Clistocoeloma sinense } \\
\text { Parasesarma pictum } \\
\text { Scopimera globosa }\end{array}$ & $\begin{array}{l}+ \\
+ \\
+ \\
+ \\
+ \\
+\end{array}$ & & - & & & $*$ \\
\hline Assiminea parasitologica & & & - & & & $*$ \\
\hline $\begin{array}{l}\text { Ligia cinerascens } \\
\text { Parasesarma affine } \\
\text { Chiromantes haematocheir }\end{array}$ & $\begin{array}{l}+ \\
+\end{array}$ & & & & & $\begin{array}{l}* \\
* \\
*\end{array}$ \\
\hline Angustassiminea yoshidayukioi & & & & & & $*$ \\
\hline Sesarmops intermedium & & & & + & & $*$ \\
\hline Batillaria attramentaria & & & & & & $*$ \\
\hline $\begin{array}{l}\text { Deiratonotus cristatus } \\
\text { Perisesarma bidens } \\
\text { Hemigrapsus penicillatus }\end{array}$ & & & & - & & * \\
\hline Batillaria multiformis & & & & & & $*$ \\
\hline Helicana japonica & & & & - & & $*$ \\
\hline Cerithidea rhizophorarum & & & & & & $*$ \\
\hline
\end{tabular}

の在・不在とその生息環境要因を調査し, 両者の関係を解 析した。塩性湿地に生息する無脊椎動物の在・不在と環境 要因との関係において, 東京湾と同様の広域スケール（10 〜100 km）では塩分と地盤高が，局所スケール（10〜 $100 \mathrm{~m}$ ）では底質粒度や酸化還元電位などが, 各種の分布 を規定する環境要因として知られている（Levin \& Talley 2002; Reiss et al. 2011). 本研究では東京湾という内湾全体 の広域スケールでのベントスの分布と環境要因との対応を 解析したので, 底質粒度よりも塩分と地盤高に応答しやす かったと考えられる. また, 地理的に偏在的な出現傾向を 示したベントスとして, ホソウミニナ, ウミニナ, フトへ ナタリ，クシテガニ，ヒメアシ八ラガニ，アリアケモドキ は湾東岸域に，またヒナタムシヤドリカワザンショウ，ヨ シダカワザンショウ, ベンケイガニは湾西岸域に出現した (Fig. 3)。これらの種の生息には塩分, 底質粒度, 地盤高 などの環境要因が関係していることが示され，そのほとん どが塩性湿地に依存的に生息している希少種・絶滅危惧種 であった。一方, 湾岸全体にわたり生息が確認できたベン トスは, 主に塩分との関係が認められ, それらは塩性湿地 内およびその周縁の干潟域でも生息できる甲殼類であっ た。

分類群ごとに見ると, 腹足類の偏在的な出現傾向は環境 要因では説明されず，主に空間的自己相関で説明された。 一方, カ二類の属する甲殼類の偏在的な出現傾向は環境要
因で説明される傾向が強かった。これら偏在分布と環境要 因の対応についての原因を以下で詳説する.

\section{ベントス分布特性と塩性湿地内の環境}

腹足類においては，カワザンショウ科のヒナタムシヤド リカワザンショウ（Fig. 3J)，ヨシダカワザンショウ（Fig. 3N）が湾西岸奥部に，またウミニナ科・フトへナタリ科 のホソウミニナ (Fig. 3P), ウミニナ (Fig. 3T), フトヘナ タリ（Fig. 3V）が湾東岸にそれぞれ偏在的に出現した。 一方，クリイロカワザンショウ（Fig. 3C）は湾岸全域に出 現し偏在性はなかった。一般的にウミニナ科・フトへナタ リ科（山本・和田 1999; 真木ら 2002; 和田・西川 2005）や カワザンショウ科（木村・木村 1999; 田代ら 2001; 福田 2000; Kuroda et al. 2003）では，塩性湿地内の塩分勾配，底 質粒度，潮位に関連した地盤高などの環境条件で出現種か 異なることが報告されている，今回，腹足類ではヒナタム シヤドリカワザンショウのみで底質粒径中央值が負の独立 効果, すなわち泥分が多い塩性湿地で出現する傾向が示さ れたが, 先行研究で本種は地盤高（木村・木村 1999）, 塩 分（Kuroda et al.2003）が分布に影響するとされ，底質粒 度は影響しないとされる。また，ヒナタムシャドリカワザ ンショウおよび同様に湾内での偏在的な出現傾向がみられ たヨシダカワザンショウの両種は, 河口域中流および上流 に分布すると報告されている（Kuroda et al. 2003）。東京湾 


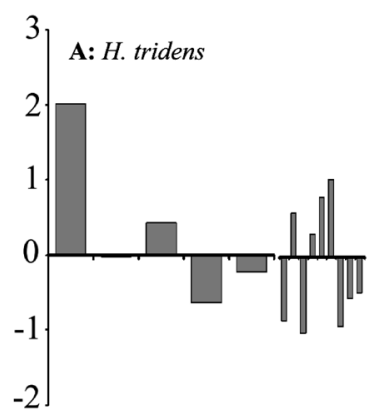

B: A.japonica

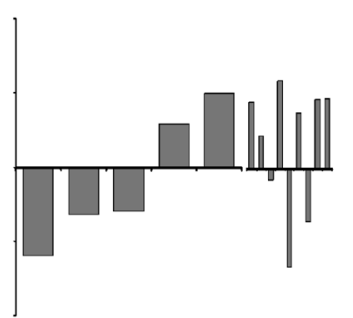

E: $M$. japonicus
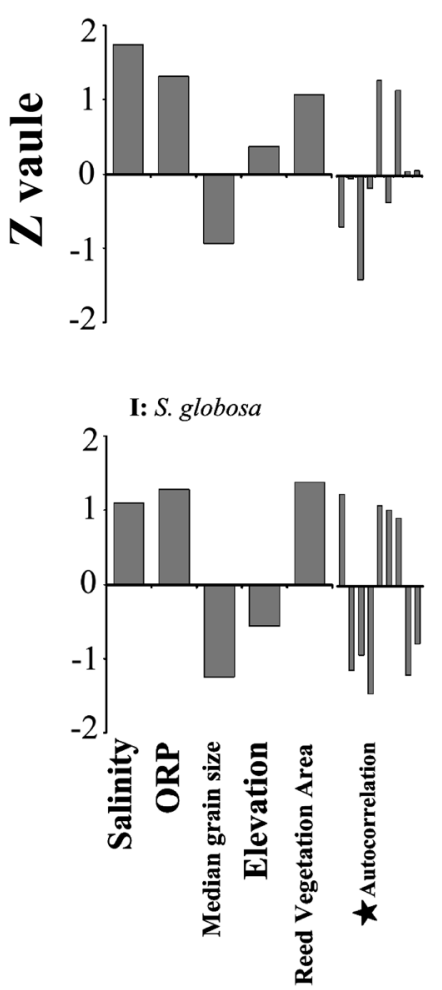

F: I. pusilla

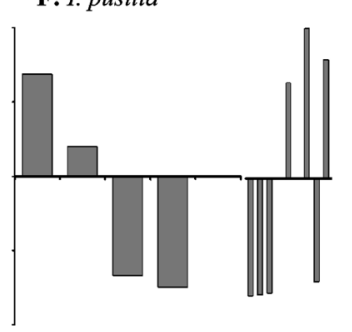

J: A. parasitologica
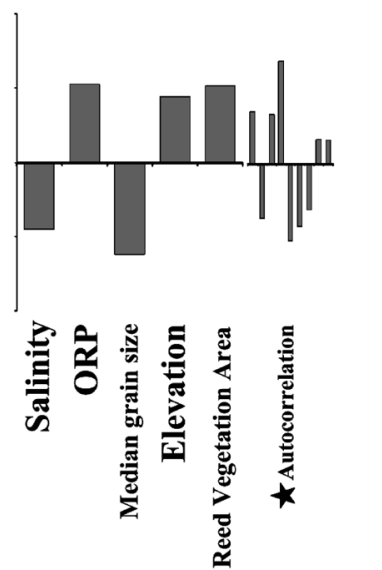

C: A. castanea
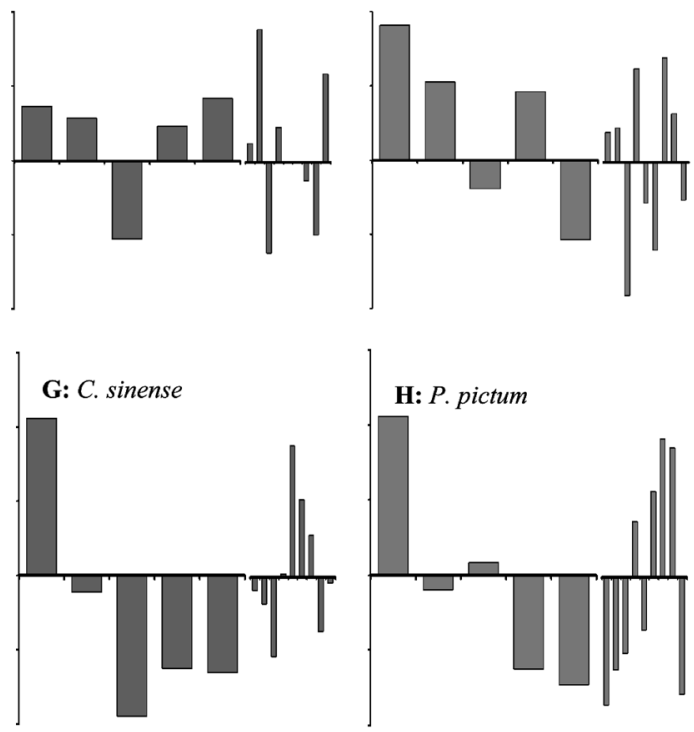

Fig. 4. Influence of each environmental variable on occurrence of the macrobenthic species.

内で最も広い河口域を持つ荒川と多摩川は湾西岸奥部で近 接して位置しているため, これらの河川干潟に生息する絶 滅危惧の腹足類各種の出現傾向に対して, 偏在性を示す空 間的自己相関が検出されたのは，底質環境要因より大河川 の存在による地理的環境の反映かもしれない。また，ウミ ニナ, フトヘナタリの出現傾向は環境要因で説明されな かったが，有意な空間的自己相関がみられた。これらの種 については, 今回計測していない環境要因の影響もしく は, 夏季に底層で貧酸素水塊が出現することに伴う底層貧 酸素水による幼生分散の阻害 (風呂田 2000 ; 丸茂・横田 2012), 生息場での他のベントスとの競合などの, 生物学 的要因によって偏在的な出現傾向を示した可能性も考えら れる.

河口域に生息する甲殼類の分布を規定する要因として, 腹足類と同様に生息場の塩分, 底質粒度, 地盤高などが挙
げられている（Ono 1965; 橋口・三宅 1967; 和田・土屋 1975; Nakasone 1977; Frusher et al. 1994; 小林 2000, Diele et al. 2010; 戸田ら 2010; 大谷ら 2012). 湾東岸に偏在的に出 現したヒメアシハラガニでは（Fig. 3U), 地盤高が本種の 出現に負の影響を与えていた. 本種は近縁種のアシハラガ ニよりも低潮位帯に生息することが示されており（Omori et al. 1998; Omori et al. 2006), 低潮位の干潟域までの連続 的な環境を必要としている可能性がある。また湾東岸と湾 奥部に偏在的に出現したクシテガニは (Fig. 3L), 塩分が 本種の出現に正の影響を与えていた. クシテガニは淡水域 には生息しないとされ（橋口・三宅 1967）, 本研究でも淡 水域を含み塩分が低い旧江戸川, 荒川, 多摩川など湾西岸 域にある大型河川河口の塩性湿地には生息していなかっ た。一方東岸に偏在的に出現したアリアケモドキは（Fig. $3 \mathrm{Q})$ ，低塩分耐性が高く河口域上流部に生息するとされる 

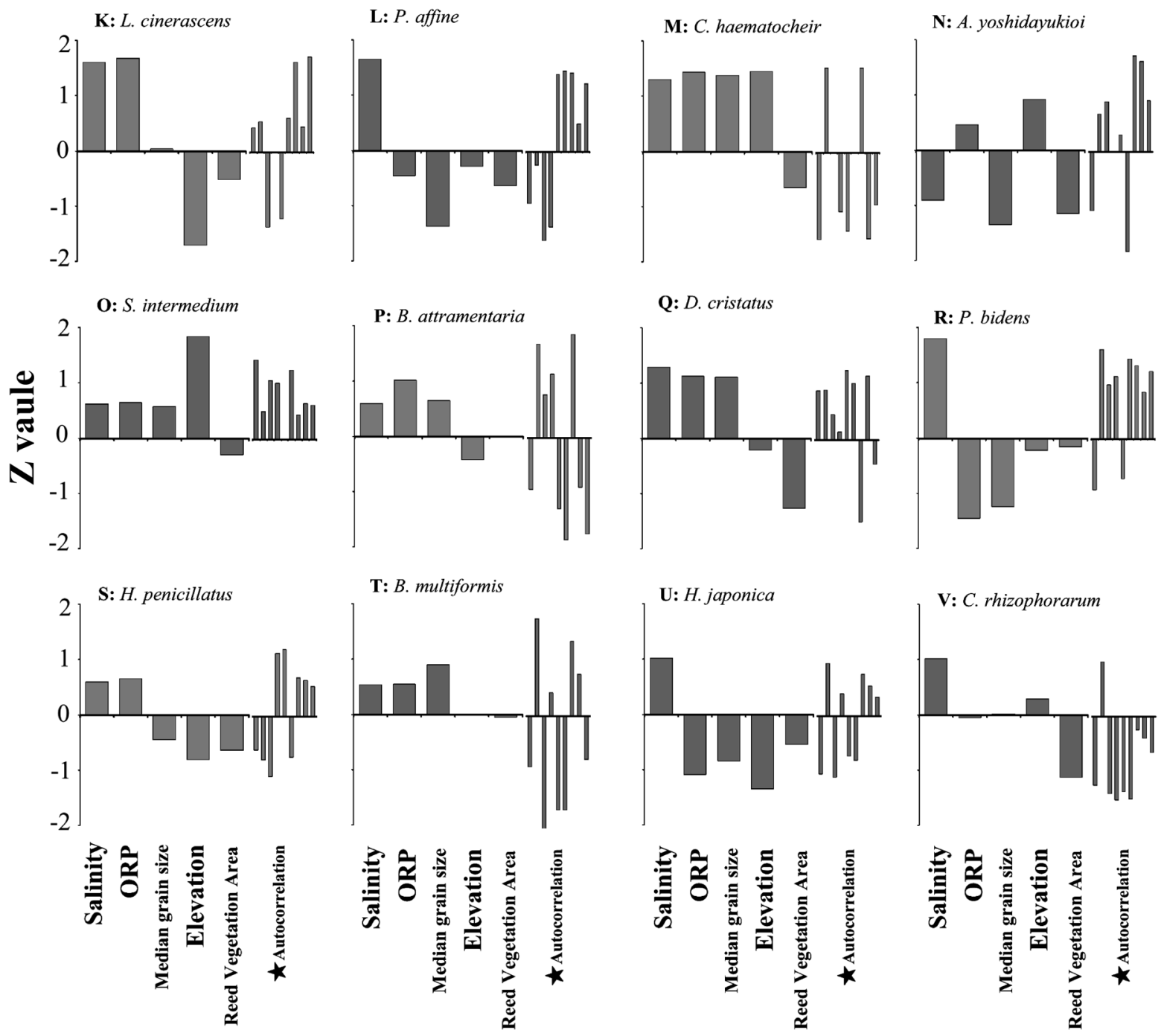

Fig. 4. continued

が（Ono 1965; 岸野ら 2010），1952 年には本種の生息が報 告されている比較的大型の河川である荒川, 多摩川, 鶴見 川（蒲生 1965）では今回生息は確認できなかった。湾西 岸・湾奥部に偏在的に出現したベンケイガニでは（Fig. 30), 地盤高が本種の出現に正の影響を与えていた. ベン ケイガニは半陸生ガニであり, 土手の斜面に巣穴を作るこ とが知られている（松田・上甫木 2004）。本種の生息が確 認された新浜湖や多摩川では, 汀線から離れた樹林や樹林 に隣接する草地でも多く見られ，一方生息が確認されな かった湾東岸の水路干潟群は潮上帯がコンクリートで護岸 されており, 本種の生息には塩性湿地とともに陸生植生帯 が必要と考えられ, 湿地と陸生植生帯の物理的分断が本種 の生息を抑制している可能性が高い。

湾岸全域で広く生息が確認されたウモレベンケイガニに 関しては (Fig. 3G), 塩分が正, 底質中央粒径值が負の影 響を与えており，比較的塩分が高い泥質底に生息してい た。ウモレベンケイガニは河口域の塩性湿地の高潮帯に依
存的に生息することが知られているが（橋口・三宅 1967), 生息場所が類似しているクシテガニと同様に, 低 塩分条件が出現を抑制したのであろう。またウモレベンケ イガニは甲幅に泥を付着させて周辺環境の泥質表面と同化 させる行動をとるので（Hsueh \& Huang 1996）, 生息環境 に泥質が必須とされ, 本解析結果でも泥底を選好する傾向 が示された.さらに本種は通常は漂着木材などの下に隠れ て生活し, その行動範囲は狭いことから（Yuhara \& Furota 2014), 塩分低下が著しくない泥質を伴う小規模な塩性湿 地が人工的な水路内に広く存在していることが, 東京湾で の個体群の存続を支えていると考えられる。

また湾岸全域で広く生息が確認された甲殼類に対して は, 概ね塩分が正の影響を与えていた、コメツキガニ, ヤ マトオサガニ, チゴガニなどのスナガニ類では, 河口域上 流部の低塩分域では分布が制限されているとされ (Ono1965), 東京湾でも低塩分の荒川や多摩川などの河口 域上流部で出現しなかった結果と一致する。またケフサイ 


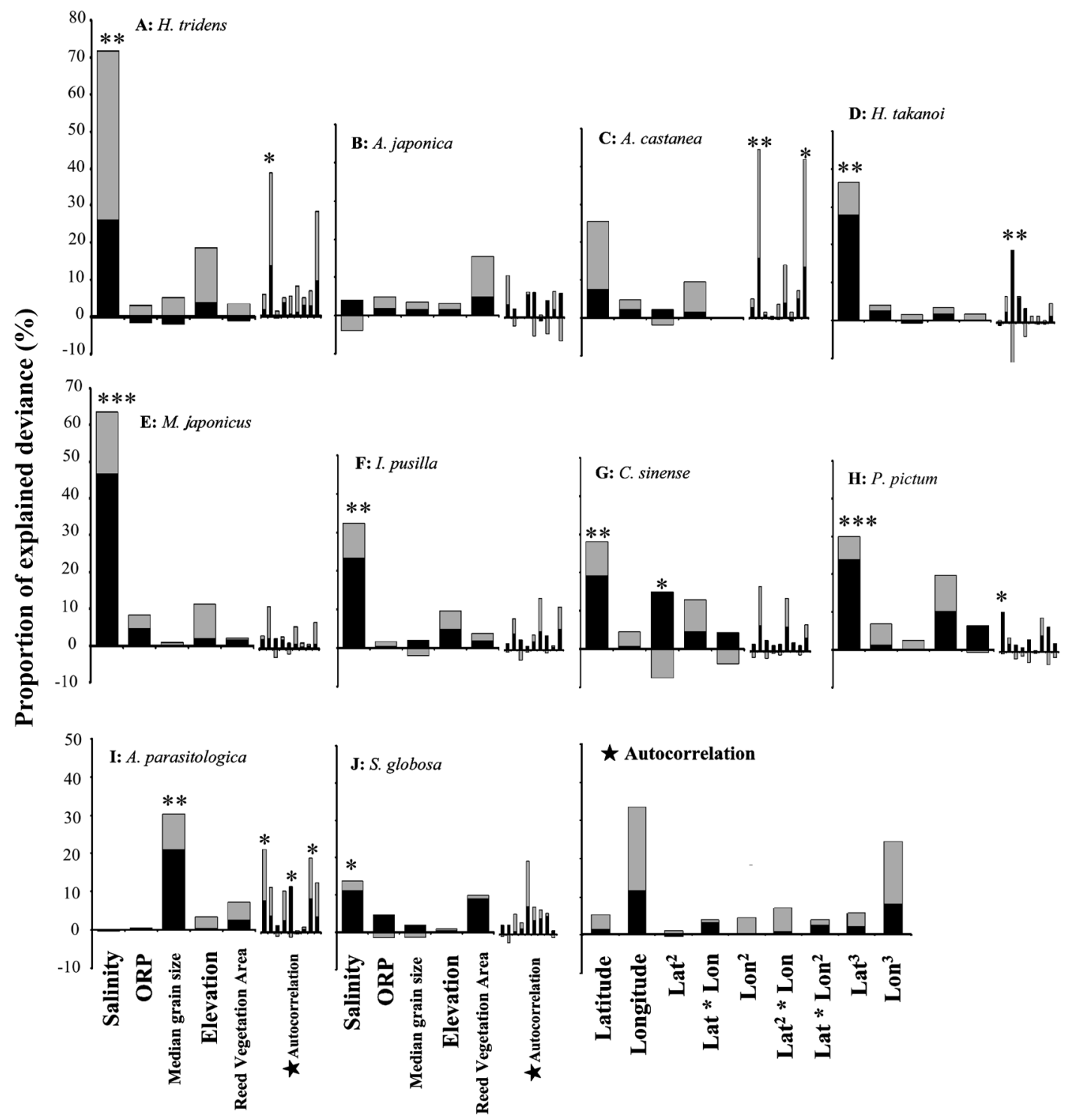

Fig. 5. Results of hierarchical partitioning explaining spatial distribution of the macrobenthic species. Dark and gray bars indicate proportions of deviance (\%) explained by independent and joint effects of each explanatory variable, respectively. The asterisk indicates a significant effect $\left({ }^{*} P<\right.$ $\left.0.05,{ }^{* *} P<0.01,{ }^{* * *} P<0.001\right)$ of the independent contribution of each variable.

ソガニの出現に対しては地盤高が負の影響を与えていた が, 本種は近縁種のタカノケフサイソガニと同様に，塩性 湿地を含めたその周縁部の干潟域から低地盤高の潮間帯下 部や潮下帯が, 主な生息場（五嶋ら 1978; van den Brink et al. 2012）であることの反映であろう.

\section{過去の東京湾ベントス相の記録との比較}

1950 年代以前の東京湾をはじめ日本各地の内湾域には 干潟が連続的に存在し，多くの河川で，河口開口部には規 模の大小はあるものの塩性湿地を伴う泥干潟が付随してい た（Sato 2010）。したがって当時は，湾内の各局所個体群 から放出された塩性湿地依存性のベントス幼生がベントス 生活の可能な場所へ到達し着底できる確率は, 多くの干潟
や塩性湿地が消失した現在と比べ高かったことは確実であ る（風呂田 2000）。現在東京湾の湾奥部と東岸域に偏在的 に分布している希少・絶滅危惧種の中に, 20 世紀半ばの 東京湾では湾西岸を含め湾岸全域に分布していた種がい る. 例えば現在, 湾東岸部の小櫃川河口干潟と東岸人工水 路干潟群に分布しているウミニナ（Fig. 3T）は，1990年 代半ばまでは江戸川放水路や谷津干潟などの湾奥部の複数 箇所や横浜など湾西岸を含め湾岸全域で生息していた（稲 葉 1955; 磯野 1960; Fukuda 1994; Furota et al. 2002; 黒住 2003; 風呂田 2007)。 またアリアケモドキは現在湾東岸人工水路 干潟群および湾奥部で確認されているが (Fig. 3Q), 1950 年代までは湾西岸の荒川, 多摩川, 鶴見川で生息記録があ り（蒲生 1965）, 当時は東京湾全域に分布していたと推察 


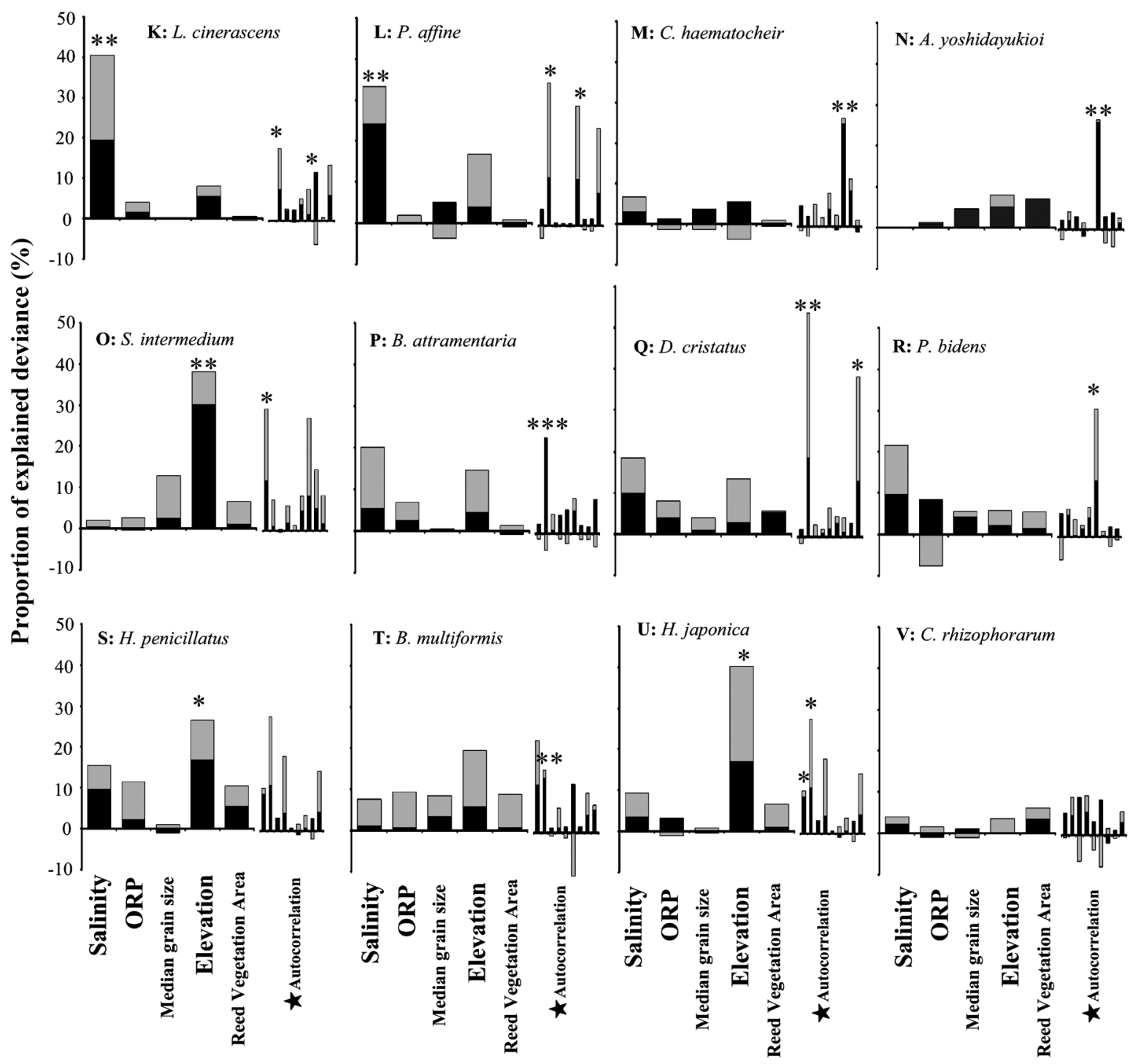

Fig. 5. continued

される.しかしながら，現在湾西岸域や湾奥に偏在的に分 布するベンケイガニでは（Fig. 30），1979 年の調査におい て, 湾東岸域の小櫃川河口干潟で確認されておらず（大 嶋・風呂田 1980)，もともと湾東岸には生息していなかっ た可能性もある。このように, 現在湾内で偏在的な分布を 示す種においても，一部を除いてかつては東京湾岸全域で 分布しているとされており, 分布の偏在性は 20 世紀後半 以降の局所的個体群の生息地の減少と理解される。このこ とからも，多くの種で生息場消失に伴う湾内での局所個体 群間の連結性の低下により，東京湾内のベントス各種のメ 夕個体群の存続性が大きく低下していると推測される.

\section{絶滅危惧種の保全のための適正な生息場とその配置}

今回の東京湾内の調査で希少・絶滅危惧種の多くでその 分布に地理的な偏在性がみられた. 現在見られる塩性湿地
は小規模なものが多く，生息地内で塩性湿地性ベントス各 種の底質環境選択性を満たす微環境の多様性が維持されて いないことに，この偏在化の原因があると推察される。多 くの生物種の地域的な絶滅過程では, 生息地の減少と分断 化による局所個体群規模の減少の進行を経て生じており, 現在東京湾における塩性湿地を伴う干潟の大幅な減少と点 在化，ならびにその中で生じている各種の分布域の偏在化 は，これらの種が東京湾での地域的絶滅の危険性が高いこ とを示している。これらの東京湾の塩性湿地依存性ベント 久各種は，東京湾で幼生分散を通じたメ夕個体群を形成し ていると考えられ（風呂田 2000; Yuhara et al. 2014），局所 個体群間の幼生分散による連結性の強化（Hanski 1999; 堀 2012），と同時に局所個体群内の生息環境の質の多様性回 復が求められる（Thomas et al. 2001; Fleishman et al. 2002）. 塩性湿地を伴う干潟は東京湾西岸つまり神奈川県海岸 
と, 湾奥千葉市海岸において大きく久落しており, この地 域での塩性湿地の再生は局所個体群間の連結性を増すのに 効果的であろう。1950 年代の鶴見川では, 塩性湿地依存 性のベンケイガニ, ウモレベンケイガニ, アリアケモドキ の生息が報告されており（蒲生 1965）, 例えばその河口部 に塩性湿地を造成することで, 幼生の着底場および生息場 となることが期待される。 また生息場の質に関して, 塩性 湿地依存性ベントス各種の選好性を満たす環境の多様性確 保には, 基本的に陸域あるいは淡水域から海域への連続し た緩やかな変化を可能にする空間的広さが求められる. 湾 東岸では塩性湿地のあるものの低地盤の人工水路干潟が中 心で, 陸域か護岸によって阻まれ, 河川敷を伴う高地盤域 に乏しくベンケイガニが生息していない可能性が示唆され た.よって湾東岸では, 生息場に潮間帯から潮上帯まで連 続性を確保するなど環境異質性に配慮し, 修復する必要で あることが示された。また空間的限界がある場合において は, 分布の偏在性が大きく, より絶滅の可能性の高い塩性 湿地性ベントスの生息場選好性を考慮した塩性湿地環境の 再生を優先することが求められる.

謝辞: 本研究を行うにあたり, 東邦大学の大越健嗣教授, 鏡味 麻衣子准教授, 西廣淳准教授, および奈良女子大学の和田恵次教 授には様々な有益にご助言を頂きました。 ベントス各種の同定に は東邦大学の多留聖典博士および多々良有紀氏のご助言を頂きま した．本稿の改訂に際し，2名の匿名査読者より貴重なご意見を 頂きました，以上を記して謝意を表します。

\section{引用文献}

Burnham, K. P. and D. R. Anderson 2002. Model selection and multimodel inference: A practical information-theoretic approach, 2nd ed. Springer, New York.

千葉県レッドデータブック改訂委員会 2011. 千葉県の保護上重要 な野生動物一千葉県レッドデータブック一動物編 2011 年 改 訂版, 千葉県環境生活部自然保護課, 千葉, $538 \mathrm{pp}$.

Diele, K., V. Koch, F. A. Abrunhosa, J. F. Lima and S. D. J. Brito 2010. The brachyuran crab community of the Caeté estuary, north Brazil: Species richness, zonation and abundance. Ecological Studies, 211: 251-263.

Fleishman, E., C. Ray, P. Sjögren-Gulve, C. L. Boggs, and D. D. Murphy 2002. Assessing the roles of patch quality, area, and isolation in predicting metapopulation dynamics. Conservation Biology, 16: 706-716.

Frusher, S. D., R. L. Giddins and T. J. Smith III 1994. Distribution and abundance of grapsid crabs (Grapsidae) in a mangrove estuary: Effects of sediment characteristics, salinity tolerances, and osmoregulatory ability. Estuaries, 17: 647-654.

Fukuda, H. 1994. Estuarine mollusks of the Edogawa Drain, central Honshu Japan. Science Report of the Takao Museum of Natural Histo$r y, 16: 1-14$.

福田 宏 2000. 巻貝類 $\mathrm{I}$ 一総論. 佐藤正典 (編), 有明海の生き ものたち, 海游舎, 東京, pp. 100-137.

風呂田利夫 2000 . 内湾の貝類, 絶滅と保全一東京湾のウミニナ類 衰退からの考察一. 月刊海洋号外, 20: 74-82.

風呂田利夫 2007. 東京湾. 飯島明子 (編), 第 7 回自然環境保全 基礎調査 浅海域生態系調査（干潟調査）業務報告書, 環境省 自然環境局生物多様性センター, 富士吉田, pp. 39-47.
風呂田利夫 2011. 小型底生動物. 東京湾海洋環境研究委員会 (編), 東京湾一人と自然のかかわりあいの再生一, 恒星社厚生 閣, 東京, pp. 136-143.

Furota, T., T. Sunobe and S. Arita 2002. Contrasting population status between the planktonic and direct-developing Batillariid snails Batillaria multiformis (Lischke) and B. cumingi (Crosse) on an isolated tidal flat in Tokyo Bay. Venus, 61: 15-23.

風呂田利夫 - 柚原 剛 - 中山聖子 - 多留聖典 - 加納光樹 2012. 地 震と津波による東京湾干潟の地形変化と底質擋乱. 日本ベント 又学会誌, 66: 126-129.

古川恵太 2011. 沿岸の埋立 -干潟の消失や海岸部の立入禁止区域 の拡大過程. 東京湾海洋環境研究委員会 (編), 東京湾一人と 自然のかかわりあいの再生一, 恒星社厚生閣, 東京, pp. 44-46. 蒲生重男 1965. 河口産カ二類の種類と分布について. 甲款類の研 究, 2: 91-101.

五嶋聖治・伊沢雅子・小野勇一 1978. イワガニ類の生活場所と日 周期活動 (予報)。 ベントス研究会連絡誌, 15/16: 28-33.

Grimm, V., K. Reise and M. Strasser 2003. Marine metapopulation: A useful concept? Helgoland Marine Research, 56: 222-228.

Hanski, I. 1999. Habitat connectivity, habitat continuity, and metapopulations in dynamic landscapes. Oikos, 87: 209-219.

橋口義久・三宅貞祥 1967. ベンケイガニの生態 II: 生息場所, 交 尾および抱卵期. 九州大學農學部學藝雜誌, 23: 81-89.

堀 正和 2012. 海洋生態系の生態系サービス一閉鎖性水域の保全 一. 加々美康彦, 松田裕之, 白山義久, 桜井泰憲, 古谷 研, 中原裕幸 (編), 海洋生態保全学, 講談社, 東京, pp. 80-92.

堀越増興 1962 . 日本列島周辺の浅海系海域における底棲生物の海 洋生物地理, 第四紀研究, 2: 117-124.

Hsueh, P. W. and J. F. Huang 1996. A new record of Clistocoeloma sinense Shen, 1933, from Taiwan (Decapoda, Brachyura, Grapsidae, Sesarminae), with notes on its distribution and ecology. Crustaceana, 69: 63-70.

稲葉 亨 1955. “吸い上げ’ の貝類. 千葉生物学会々報, 5: 6-7.

伊藤 忠・伊藤嘉久 1983. 運河の潮位干満差を利用した雨水排除 計画. 下水道協会誌, 20: 40-48.

磯野 鮑 1960. 貝漫歩 (I). ちりぼたん， 1: 32-38.

環境省自然環境局 2007. 第 7 回自然環境保全基礎調査. 飯島明子 (編), 浅海域生態系 (干潟調査) 業務報告書. 環境省自然環境 局生物多様性センター, $236 \mathrm{pp}$.

木村昭一・木村妙子 1999. 三河湾および伊勢湾河口域におけるア シ原湿地の腹足類相. 日本ベントス学会誌, 54: 44-56.

岸野 底・木邑聡美・唐澤恒夫 - 國里美樹 - 酒野光世・野元彰 人・和田恵次 2010. 汽水性希少カ二類クマノエミオスジガニ Deiratonotus kaoriae とアリアケモドキD.cristatus (ムツハアリ アケガニ科) の三重県櫛田川河口域における出現状況. 日本心゙ ントス学会誌, 65: 6-9.

小林 哲 2000. 河川環境におけるカ二類の分布様式と生態一生態 系における役割と現状一. 応用生態工学, 3: 113-130.

Krizer, J. P. and P. F. Sale 2006. Marine Metapopulation. Elsevier, California, $544 \mathrm{pp}$.

Kumar,G., S. P. Kunal, M. R. Menezes and R. M. Meena 2012. Single genetic stock of kawakawa Euthynnus affinis (Cantor, 1849) along the Indian coast inferred from sequence analyses of mitochondrial DNA D-loop region. Conservation Genetics, 13: 1119-1131.

Kuroda, M., K. Wada, M. Kamada, K. Suzukida, H. Fukuda 2003. Distribution patterns of assimineid species (Gastropoda: Rissooidea) in the salt marshes of the Yoshino River, Tokushima Prefecture, Japan. The Yuriyagai, 9: 21-31.

黒住耐二 2003. 多摩川水系の貝類から見た自然環境の現状把握と 保全に関する研究. (財)とうきゅう環境浄化財団研究助成・学 術研究, 31: 1-242.

楠田哲也・森 敬介 2008. 河川汽水域の生物種. 財団法人河川環 境管理財団 (編), 河川汽水域一その環境特性と生態系の保 
全・再生一, 技報堂出版, 東京, pp. 171-175.

Levin, L. A. and T. S. Talley 2002. Natural and manipulated sources of heterogeneity controlling early faunal development of a salt marsh. Ecological Applications, 12: 1785-1802.

Lichstein, H. K., T. R. Simons, S. A. Bourque, R. H. Bradbury and K. E. Franzreb 2002. Spatial autocorrelation and autoregressive models in ecology. Ecological Monographs, 72: 445-463.

Lotze, H. K., H. S. Lenihan, B. J. Bourque, R. H. Bradbury, R. G. Cooke, M. C. Kay, S. M. Kidwell, M. X. Kirby, C. H. Peterson and J. B. C. Jackson 2006. Depletion, degradation, and recovery potential of estuaries and coastal seas. Science, 312: 1806-1809.

MacNally, R. 2000. Regression and model-building in conservation biology, biogeography and ecology: the distinction between - and reconciliation of - 'predictive' and 'explanatory' models. Biodiversity and Conservation, 9: 655-671.

真木英子・大滝陽美・冨山清升 2002. ウミニナ科 1 種とフトへナ タリ科 3 種の分布と底質選好性 : 特にカワアイを中心にして. Venus, 61: 61-72.

丸茂恵右・横田瑞郎 2012. 貧酸素水塊の形成および貧酸素の生物 影響に関する文献調査. 海生研研報, 15: 1-21.

松田朋子・上甫木昭春 2004. 大阪府泉南の海岸埋め立て部におけ る陸ガニの生息状況と環境特性との関係に関する研究. ランド スケープ研究, 67: 537-542.

Nakasone, Y. 1977. Crab zonation in the Yuhi River, Okinawa Island. Japanese Journal of Ecology, 27: 61-70.

永江雅和 2006. 長浦干拓地の工業転用問題. 千葉県史研究, 14: 50-67.

中瀬浩太・林 英子 2002 . 埋立地に造成した人工干潟の環境変化 と環境管理一東京港野鳥公園の事例一. 海洋開発論文集, 18: 31-36.

日本ベントス学会干潟 RDB 編集委員会 2012. 干潟の絶滅危惧動 物図鑑一海岸ベントスのレッドデータブック, 東海大学出版 会, 秦野, $306 \mathrm{pp}$.

農業環境技術研究所 歴史的環境閲覧システム http://habs.dc.affrc. go.jp/ [2013 年 12 月 25 日閲覧 $]$

小幡智子 - 石井 潤 - 角谷 拓・鷲谷いづみ 2012. 渡良瀬遊水地 における過去の掘削履歴が絶滅危惧植物の現在の分布に及ぼす 影響と影響評価地図。保全生態学研究，17: 221-233.

大谷壮介 -上月康則 - 倉田健悟 - 山中亮一 2012. 干潟の底質環境 に対する底生生物群集予測モデルの提案. 応用生態工学, 15 : $31-44$.

岡本正豊 2005. いつまで棲息していたか小櫃川河口のへナタリ 類. ちりぼたん, 35: 114-118.

Omori, K., B. Irawan and Y. Kikutani 1998. Studies on the salinity and desiccation tolerances of Helice tridens and Helice japonica (Decapoda: Grapsidae). Hydrobiologia, 386: 27-36.

Omori, K., Y. Kikutani, B. Irawan and Y. Goda 2006. Size-Dependent intraguild reciprocal predation between Helice tridens De Haan and $H$. japonica Sakai and Yatsuzuka (Decapoda: Grapsidae) as analyzed in field experiments. Journal of Crustacean Biology, 26: 148-153.

Ono, Y. 1965. On the ecological distribution of ocypoid crabs in the estuary. The Memoirs of the Faculty of Science, Kyushu University, Series E (Biology), 4: 1-60.

大嶋 剛・風呂田利夫 1980. 小櫃川河口干潟周辺における底生動 物の分布. 千葉県木更津市小櫃川河口干潟の生態学的研究 I,
東邦大学理学部海洋生物研究室 -千葉県生物学会共編, pp. 4568.

プリマック RB・小堀洋美 2008. 保全生物学のすすめ 改訂版一 生物多様性保全のための学際的アプローチ一, 文一総合出版, 東京, $396 \mathrm{pp}$.

R Core Team. 2012. R: A language and environment for statistical computing. Vienna, Austria. URL http://www.R-project.org/

Reiss, H., S. Cunze, K. König, H. Neumann and I. Kröncke 2011. Species distribution modeling of marine benthos: A North Sea case study. Marine Ecological Progress Series, 442: 71-86.

酒井 恒 1976. 日本産蟹類, 講談社, 東京, 773 pp.

Sale, P. F., I. Hanski and J. P. Kritzer 2006. The merging of metapopulation theory and marine ecology: establishing the historical context. In Marine Metapopulations, Kritzer, J. P. and P. F. Sale (eds), Elservier acadimc press, Amsterdam, pp. 3-28.

Sato, M. 2010. Anthropogenic decline of the peculiar fauna of estuarine mudflats in Japan. Plankton and Benthos Research, 5 (Supplement): 202-213.

Takeda, S. and Y. Kurihara 1987. The effects of burrowing of Helice tridens (De Haan) on the soil of a salt-marsh habitat, Journal of Experimental Marine Biology and Ecology, 113: 79-89.

田代美穂・冨山清升・森野 浩 2001. 涸沼水系におけるカワザン ショウガイの分布と各地域集団の個体群構造. Venus, 60: 81-93.

Thomas, J. A., N. A. Bourn, R. T. Clarke, K. E. Stewart, D. J. Simcox, G. S. Pearman, R. Curtis and B. Goodger 2001. The quality and isolation of habitat patches both determine where butterflies persist in fragmented landscapes. Proceedings of the Royal Society B: Biological Sciences, 268: 1791-1796.

戸田健太郎・中村彰宏・塩井景介・前中久行 2010. 男里川河口部 における土壌および微地形の違いに対するカ二類 3 種の分布域 に関する研究. ランドスケープ研究, 73: 441-446.

van den Brink, A. M., S. Wijnhoven and C. L. McLay 2012. Competition and niche segregation following the arrival of Hemigrapsus takanoi in the formerly Carcinus maenas dominated Dutch delta. Journal of Sea Research, 73: 126-136.

和田恵次・西川知絵 2005. 河口域塩性湿地に生息する巻貝フトへ ナタリ（腹足綱：フトヘナタリ科）の生息場所利用. 日本ベン トス学会誌, 60: 23-29.

和田恵次・土屋 誠 1975. 蒲生干潟における潮位高と底質からみ たスナガニ類の分布. 日本生態学会誌，25: 235-238.

山本百合亜・和田恵次 1999. 干潟に生息するウミニナ科貝類 4 種 の分布とその要因. 南紀生物, 41: 15-22.

柚原 剛・多留聖典・風呂田利夫 2013. 東京湾における干潟ベン トスの分布と希少種を含む生物多様性保全における人工水路の 重要性. 日本ベントス学会誌, 68: 16-27.

Yuhara, T. and T. Furota 2014. Life history and stable regeneration of the endangered saltmarsh sesarmid crab Clistocoeloma sinense in small populations of the isolated metapopulation of Tokyo Bay, Japan. Plankton and Benthos Research, 9: 114-121.

Yuhara, T., M. Kawane and T. Furota 2014. Genetic population structure of local populations the endangered saltmarsh sesarmid crab Clistocoeloma sinense in Japan. PLOS ONE, 9(1): e84720.

柚原 剛 - 田中正敦 - 阿部絢香 - 海上智央 - 多留聖典 2015. 多摩 川河口の塩性湿地に生息する表在性ベントス相. 神奈川自然誌 資料，25-30。 